\title{
Viktoriia Kovalenko,
}

PhD (Candidate of Psychological Sciences), associate professor, Department of Correctional Education and Special Psychology, Kharkiv Academy of Humanities and Pedagogy, 7, Rustaveli lane, Kharkiv, Ukraine

\section{PROGRAMME OF CORRECTION OF EMOTIONAL DEVELOPMENT DISORDERS IN MENTALLY RETARDED PRIMARY SCHOOL STUDENTS TAKING ONE-ON-ONE TRAINING}

The paper deals with the issue of correction of mentally retarded primary school students' emotional development in one-on-one training environment. The learning environment is considered as a system of correctional impact on the development of a mentally retarded child by means of creating special conditions contributing to his/her health preservation, as well as on the formation of his/her personality as an integral structure consisting of such components as cognitive processes, emotional and volitional sphere, experience (knowledge, abilities, skills, and habits), needs, interests, goals, and motives. The learning environment of one-on-one training cannot be characterised by adaptability as it cannot provide a child with the conditions contributing to his/her acquisition of culture elements considering his/her age characteristics, internal resources and opportunities, which negatively affects his/her emotional development. That is why the correction of emotional development components is an important condition of mentally retarded children's socialisation. The study aims to describe the developed complex programme of correction of mentally retarded primary school students' (taking one-on-one training) emotional development. The programme is based on the technologies of direct and indirect influence. The technology of direct influence is applied to correct and develop the emotional sphere of mentally retarded school students. It involves the lessons of individual and group correction in terms of behavioural approach to psychocorrection. The technology of indirect influence is focused on the maximum realisation of correctional opportunities of the learning environment (home conditions). It provides the reconstruction of environmental and subject, psycho-didactic and social conditions which have an indirect impact on the harmonisation of the components of emotional development. The efficiency of the suggested programme has been proven by conducting the experiment among mentally retarded children living in some cities of Ukraine (Henichesk, Petrovske, Luhansk).

Keywords: emotional development, intellectual disability, one-on-one training, correction, programme.

\section{Introduction}

At present, the state's interest in relation to special education is targeted at providing all the children suffering from psychophysical disorders with appropriate education taking into account their individual needs, abilities, capabilities, and interests in the learning environment that is appropriate to their health state. One-on-one training in the system of general secondary education is one of the forms of educational process organisation that ensures the rights of mentally retarded people for getting general secondary education at comprehensive educational institutions of all forms of ownership [3]. However, being trained one-on-one, a mentally retarded child is put in deprivational social situation of development, his/her social circle is limited by interaction with teachers and parents, does not involve extensive communication with equals in age, which has negative impact on his/her emotional development.

The issue of mentally retarded children's emotional development was covered in the works of I. Bhazhnokova, L. Zankova, N. Kolominskyi, Zh. Nazambaieva, V. Petrova, O. Proskurniak, S. Rubinshtein, L. Rudenko, V. Synov, L. Shypitsyna, Zh. Shif, D. Shulzhenko [1; 4; 5 ; 6]. The study of emotional development of mentally retarded children taking one-on-one training was conduct- ed by A. Kolupaieva, V. Kovalenko, O. Shapovalova, L. Shypitsyna, N. Shkliar. In particular, N. Shkliar noted that lack of communication makes the development of mentally retarded child's psyche difficult $[5 ; 6]$. V. Kovalenko drew attention to disorders with the cognitive component of emotional development of mentally retarded children taking one-on-one training, which is manifested in the restriction of the range of emotional experiences, their simplification and sameness; these children's emotional states are characterised by inner stress, interpersonal and educational anxiety. The instrumental component of emotional development is manifested in domination of negative emotional background; the children have disorders with the intensity of emotional expressions in the form of emotional response to emotive situations, stability of emotional responses, disorders of emotional responses to teacher's evaluation, adequacy and control defects [1; $4 ; 6]$. Consequently, the issue of correction of emotional development of mentally retarded primary school children taking one-on-one training is of particular interest at present.

The aim of the paper is theoretical substantiation of the developed comprehensive programme for correction of emotional development of mentally retarded primary school students taking one-on-one training. 
The tasks of the paper: to analyse the conception of correcting emotional development disorders in mentally retarded primary school students; to substantiate the reasonability of using technologies of direct and indirect influence on emotional development of mentally retarded students taking one-on-one training; to characterise the content of the comprehensive programme for correcting emotional development disorders.

Research methods: review of scientific literature, substantiation; conceptualisation of theory, summarising scientific achievements.

\section{Discussion}

Correction of the content-related and instrumental components of emotional development is an important prerequisite for improving socialisation process of mentally retarded primary school students, normalisation of their contacts with people around them and harmonisation of their personalities' development (Yu. Bystrova, V. Bodnar, N. Kolominskyi, S. Rubinshtein, V. Synov, D. Shulzhenko). Considering the issue of correcting emotional development disorders, it is reasonable to mention a set of correctional and developmental events aimed at overcoming negative emotional states, malfunction or retardation of the development of the content-related and instrumental components of child's emotional sphere, as well as compensation of negative personality traits developed on the basis of these disorders. Correction of emotional development disorders is provided by means of comprehensive approach, which involves organisation of correctional and developmental influence on the emotional sphere using the technologies of direct and indirect influence. The first technology is targeted at correction and development of mentally retarded primary school students, actualisation of compensatory abilities and includes holding classes according to the programme of individual and group correction.

Theoretical background for the technology of indirect influence is the idea of "environmental pedagogy" theory and technology of indirect control (through the environment) over the process of child personality formation and development (Ye. Slepovych, Yu. Manuilov, S. Shatskyi). Accordingly, the technology of indirect influence is focused on the fullest possible implementation of correctional capacity of a learning environment and involves reorganisation of environemental and subject, psycho-didactic and social conditions of it (V. Yasvin).

Regarding the technology of direct influence, strategies and techniques of psychological correction are chosen according to activity approach, which implies correction by means of special teaching. In behavioural approach, the concept "emotional development" is related to the concept "emotional sphere". In this case, dynamics of teaching is provided by development from simple forms of learning (habituation) to more complicated, spontaneous ones. Complicated forms of emotional teaching are associated with the emerging of associations between events or stimuli, which form the system of emotional responses that will determine the specific character of child's emotional experience [2].

There are two stages in the structure of the correction programme: the stage of individual and group sessions. The stage of individual sessions includes the main period $\left(1^{\text {st }}-9^{\text {th }}\right.$ session $)$ and the summarising one $\left(10^{\text {th }}-15^{\text {th }}\right.$ session). At this stage, rhythmic games and exercises, problem-based situations are widely used. Besides, this stage involves the use of some elements of fairy tale therapy with improvisation, some elements of psychodrama, psychogymastics, rhythm and roleplaying games and exercises, drawing musical images, blob drawings, dumb show, children's simulations of various emotional states.

During the main period of individual sessions with children, the system of cognitive and affective ideas about basic emotions (joy, sadness, anger, disgust, contempt, guilt, shame, surprise, interest - K. Izard) is developed, in practical situations the children are shown the opportunities of emotional response through external expressive means of demonstration (facial expressions, pantomimicry, gestures); children's range of emotional experiences is being enriched; the development of proper perception of other people's emotional reactions according to expressive indicators and the ability to distinguish one's own emotional reactions, name them and express in a socially acceptable way is observed.

Let us give an example. The aim of the first session of the programme was the development of cognitive and affective scheme of ideas about joy as an emotion, informing about the ways of emphatic expression of emotions (facial expressions, pantomimicry, gestures), enrichment of the range of emotional experiences, development of proper perception, the understanding and identification of joy, the ability for spontaneous simulation of joy, analysing one's own expressive demonstrations of joy.

During the session the psychologist suggests that the child goes to an unusual town peopled with different inhabitants: kind and evil, merry and sad, interesting and boring. First, they visit residents living in the first house of the town. The psychologist presents a small house; in order to find out who lives in this house, the child is supposed to create an emotional pictogram consisting of two parts (joy emotion) and determine the resident's mood according to the pictogram. Thus, every session the children are made familiar with basic emotions, they analyse expressive gestures of a person who is experiencing a certain emotion; the psychologist teaches children how to spontaneously reproduce a certain emotion by means of simulation and role-based solving of a problem-based situation, forms the command of means and techniques of expressing emotions and feelings in socially accepted forms. At the end of the session, the psychologist holds a communicative "game-optimiser" intended for the formation of positive attitude to the session.

The summarising period of the individual sessions is characterised by systematisation of cognitive and effective ideas about basic emotions, formation of social emo- 
tions, development of emotional attitude to moral norms, the extending of the range of emotional experiences, the reducing of the level of emotional tension, development of contextual emotional regulation, stabilisation of mood. By means of comparing content-related and instrumental components of opposite emotions and reasons for their emergence, the cognitive and affective ideas about emotions are generalised and systematised.

Let us provide an example of the introduction to the individual session of the summarising period on the topic "Joy-sadness".

Objective: to summarise cognitive and affective ideas about emotions expressing joy and sadness, to form social emotions: compassion, sympathy; to develop emotional attitude to moral norms, to extend the range of emotional experiences, to reduce the level of emotional tension, to develop contextual emotional regulation, to stabilise mood.

Course of the session:

1. Greeting. Playing the game "Sunny and Rainy". The child sits on a chair. The psychologist says, "It's sunny! Go for a walk!". The child walks and runs around the room. After the words: "It's rainy! Go home!" the child runs back to his/her place. When the psychologist says again "It's sunny! You can go for a walk!", the game is repeated. After playing the game, the psychologist asks, "Which way did we enjoy the sun? Why? How can we understand that someone is glad and happy?".

After that the child is offered to draw the smiling happy sun: he/she draws the sun's eyes and smile on a yellow circle.

2. The exercise "Ooh and Aah". The psychologist demonstrates two identically dressed dolls (their expressive motions and facial expressions demonstrate experiencing joy and sadness). He/she says that two boys from the houses of the fairy town (pointing out at the houses with emotional pictograms) named Ooh and Aah have visited them. The boys do not remember where they live and cannot find their ways home themselves. The psychologist suggests that they should help the boys - determine their mood according to emphatic facial expressions.

3. The psychologist reads the poem by L. Zubkova "Ooh and Aah". After that he/she asks: "What do you think, which of the two is merry, Ooh or Aah? Who is sad? Who is in a good mood? Who is in a bad mood? What way are the boys alike? What way do they differ from each other? Why is Ooh sad, in your opinion? Why is Aah merry?". Then the psychologist suggests improvised imitation of joy and sadness in front of the mirror.

After the stage of individual sessions aimed at correction and development, it is reasonable to continue work in groups. Group form of work facilitates development of the system of emotional regulation of one's behaviour, as long as a mentally retarded child should control his/her behaviour in interaction with equals in age. Group work involves children (divided into subgroups of 4-5 people) who have undergone individual training. The stage of group sessions has consolidation period $\left(16^{\text {th }}-25^{\text {th }}\right.$ session). Group work with children is characterised by the expanding of cognitive and affective ideas about emotions, development of the ability for emotional regulation by means of expression (facial expressions, pantomimicry), control over emotional regulation in situation of social interaction, development of the ability for contextual emotional regulation. During the group stage of psychocorrectional sessions, roleplaying games and problembased situations are actively used. The main means of correction are play activity and elements of psychogymnastics. The auxiliary means of correction are drawing, music and sculpturing.

Let us consider the technology of indirect influence on emotional development of mentally retarded students taking one-on-one training, which implies modification of environmental and subject, psycho-didactic and social conditions of the learning environment. The main conditions of the environmental and subject component of the learning environment (i.e. home environment as the children are educated at home) are as follows: its correspondence to the requirements of ergonomics (proper illumination and colouring, temperature); division of the "classroom" into major functional areas; each functional area must be equipped with necessary resources; correspondence of furniture and equipment of the room to age and morphofunctional peculiarities of the children. The conditions of the psycho-didactic component: individual approach to teaching; use of protective pedagogical scheme; establishment of medical and pedagogical partnership with healthcare institutions by the educational institution providing one-on-one training with the aim of providing the children with a range of social, medical and educational services; holding psychological, medical and pedagogical consultations with the purpose of child's emotional state monitoring. The main conditions of the social component are as follows: formation of proper emotional attitude of parents and teachers to the child by means of holding group and individual consultations; establishment of socio-pedagogical partnership (the formation of a narrow educational circle) between the educational institution and specialised department of correctional education and special needs psychology, which is going to carry out the monitoring and scientific supervision of the organisation of one-on-one teaching for mentally retarded primary school students.

The progress of correctional and developmental impact is expressed in increasing the intensity and stability of positive dynamics of all the components and parameters of emotional development of mentally retarded primary school students.

The comprehensive correction programme elaborated by us with the aim of developing the content-related and instrumental components of emotional sphere of mentally retarded students taking one-on-one training was implemented in a number of educational institutions (located in Henichesk, Petrovske, Luhansk), and its efficiency has been proven. Positive dynamics of most indicators of emotional development of mentally retarded primary 
school students was achieved due to combined use (synergetic effect) of the technologies of direct and indirect correctional and developmental influence on emotional development [1, p. 93].

\section{Conclusions}

Integrated impact on emotional development of mentally retarded primary school students who take one-onone training is provided by means of the technologies of direct and indirect influence, which involves individual

\section{RFERENCES}

1. Kovalenko, V. Ye. (2015). Rezultaty vprovadzhennia prohramy korektsii porushen emotsiinoho rozvytku $\mathrm{v}$ uchniv indyvidualnoi formy navchannia $\mathrm{z}$ rozumovoiu vidstalistiu [Results of the implementation of the correction programme intended for emotional development of mentally retarded primary students taking one-on-one training]. V. M. Synov \& O. V. Havrylov (Eds.). Aktualni pytannia korektsiinoi osvity (pedahohichni nauky): zbirnyk naukovykh prats - Topical issues of correctional education (educational sciences): collection of scientific papers, 2, 89-98 (Vols. 6). KamianetsPodilsky: PE Medobory-2006 [in Ukrainian]

2. Vynoslavska, O. V.

BreusenkoKuznietsov, O. A., \& Zlyvkov, V. L. (2005). Psykholohiia [Psychology]. Kyiv: INKOS [in Ukrainian].

3. Polozhennia pro indyvidualnu formu navchannia $v$ zagalnoosvitnih navchalnyh zakladah vid 12.01.2016 № 8 [Regulations on the individual form of teaching in

\section{ЛІТЕРАТУРА}

1. Коваленко В. С. Результати впровадження програми корекції порушень емоційного розвитку в учнів індивідуальної форми навчання 3 розумовою відсталістю / В. С. Коваленко // Актуальні питання корекційної освіти (педагогічні науки) : збірник наукових праць у 2 т. / за ред. В. М. Синьова, О. В. Гаврилова. - Кам'янець-Подільський : ПП Медобори-2006, 2015. - Вип. 6. - Т 2. - С. 89-98.

2. Психологія / О. В. Винославська, О. А. Бреусенко-Кузнєцов, В. Л. Зливков. - К. : ІНKOC, 2005. - $351 \mathrm{c}$.

3. «Положення про індивідуальну форму навчання в загальноосвітніх навчальних закладах від and group correction and modification of the environmental and subject, psycho-didactic and social conditions of the learning environment.

Further consideration of the issue of correcting emotional development disorders is expected to be focused on studying the effectiveness of applying psychodynamic approach to psychocorrection of mentally retarded primary school students' development.

general educational institutions dated 12.01.2016/8]. Retrieved from: http://zakon2.rada.gov.ua/laws/show/z0184-16 [in Ukrainian]

4. Synov, V. M., Matvieieva, M. P., \& Khokhlina, O. P. (2008). Psykholohiia rozumovo vidstaloi dytyny [Psychology of a mentally retarded child]. Kyiv: Znannia [in Ukrainian].

5. Slepovich, Ye. S., \& Polyakov, A. M. (2008). Rabota s detmi s intellektualnoy nedostatochnostyu. Praktika spetsialnoy psikhologii [Working with children with intellectual disabilities. The practice of psychology for special needs]. Saint Petersburg: Rech [in Russian].

6. Shipitsyna, L. M. (2005). Neobuchaemyy rebenok $v$ semye $i$ obschestve. Sotsializatsiya detey $s$ narusheniem intellekta [Learning-disabled child in a family and society. Socialization of children with intellectual disabilities]. Saint Petersburg: Rech [in Russian].

12.01.2016 № 8» [Електронний ресурс]. - Режим доступу: http://zakon2.rada.gov.ua/laws/show/z0184-16.

4. Синьов В. М. Психологія розумово відсталої дитини / В. М. Синьов, М. П. Матвєєва, О. П. Хохліна. - К. : Знання, 2008. - 359 с.

5. Слепович Е. С. Работа с детьми с интеллектуальной недостаточностью. Практика специальной психологии / Е. С. Слепович, А. М. Поляков. - СПб. : Речь, 2008. - 247 с.

6. Шипицына Л. М. Необучаемый ребенок в семье и обществе. Социализация детей с нарушением интеллекта / Л. М. Шипицына. - СПб. : Речь, 2005. $477 \mathrm{c}$.

\section{кандидат психологічних наук дочерія Свгенівна Коваленко, Харківська гуманітарно-педагогічна академія, пров. Руставелі, 7, м. Харків, Украӥна}

\section{ПРОГРАМА КОРЕКЦІЇ ПОРУШЕНЬ ЕМОЦЙНОГО РОЗВИТКУ РОЗУМОВО ВІДСТАЛИХ МОЛОДШИХ ШКОЛЯРІВ ІНДИВІДУАЛЬНОЇ ФОРМИ НАВЧАННЯ}

У статті розглядається проблема корекції порушень змістового та інструментального компонентів емоційного розвитку розумово відсталих молодших школярів, які навчаються в освітньому середовищі індивідуальної форми навчання. Освітнє середовище розглядається як система корекційного впливу на хід розвитку розумово відсталого учня шляхом створення спеціальних умов (просторово-предметних, психодидактичних, соціальних), що сприяють збереженню його здоров’я та формуванню особистості як цілісної структури в єдності таких ії компонентів, як пізна- 
вальні процеси й емоційно-вольова сфера, досвід (знання, уміння, навички, звички), потреби, інтереси, цілі та мотиви. Освітнє середовище індивідуальної форми навчання втрачає свою адаптивність, адже у ньому обмежуються умови для успішного присвоєння елементів культури розумово відсталою дитиною з урахуванням ії вікових особливостей, внутрішніх ресурсів і можливостей, що негативно впливає на емоційний розвиток дітей. Тому корекція змістового й інструментального компонентів емоційного розвитку виступає важливою передумовою покращення процесу соціалізації розумово відсталих молодших школярів, нормалізації контактів із оточенням та гармонізації розвитку їхньої особистості. Метою статті є теоретичне обгрунтування комплексної програми корекції емоційного розвитку розумово відсталих молодших школярів - учнів індивідуальної форми навчання. Шляхом аналізу літературних джерел, обгрунтування, а також концептуалізації теоретичного змісту та узагальнень наукових здобутків у статті наведено комплексну програму корекції порушень емоційного розвитку шляхом організації процесу корекційнорозвивального впливу на емоційну сферу з використанням технологій прямого й опосередкованого впливу. Технологія прямого впливу спрямовується на корекцію та розвиток емоційної сфери розумово відсталих молодших школярів, актуалізацію компенсаторних можливостей і передбачає проведення занять програми індивідуально-групової корекції в аспекті поведінкового підходу психокорекції. Технологія опосередкованого впливу спрямовується на максимальну реалізацію корекційних можливостей освітнього середовища індивідуального навчання (домашніх умов). Вона передбачає перебудову просторово-предметних, психодидактичних та соціальних умов, які побічно впливають на гармонізацію змістових та інструментальних компонентів емоційного розвитку. Ефективність запропонованої програми доведено шляхом їі впровадження в освітніх закладах з учнями індивідуальної форми навчання з розумовою відсталістю.

Ключові слова: емоційний розвиток, розумова відсталість, індивідуальна форма навчання, корекція, програма.

Submitted on 18.05.2017

Reviewed by Doctor of Psychology, prof. Yu. Bystrova 